\title{
Estimation of organic matter digestibility and metabolizable energy content of agro-industrial wastes using in vitro gas production
}

\author{
E. M. Aregheore ${ }^{+}$and S.A. Abdulrazak* \\ The University of the South Pacific, School of Agriculture, Animal Science Department, Alafua \\ Campus Apia, Samoa. \\ * Shimane University, Faculty of Life and Environmental Science, Laboratory of Animal Science \\ Mutsue-shi 690-8504, Japan.
}

+Corresponding author - aregheore_m@samoa.usp.ac.fj

*Present address: Deartment of Animal Science, Egerton University, P.O. Box 536, Njoro Kenya.

\begin{abstract}
Organic matter (OM), neutral detergent fibre (NDF) digestibilities and metabolizable energy content of some available agro-industrial wastes (AIW) such as dried brewers' grains, cocoa shell, cocoa dust, desiccated coconut waste meal, wheat bran and rice bran used as ruminant feeds were estimated from in vitro gas production technique. Their crude protein (CP) content varied from $13.7-25.6 \%$, NDF ranged from 21.9 to $48.4 \%$, OM from $88.6-95.4 \%$ and non-structural carbohydrate (NSC) estimates increased from $7.2-45.6 \%$. Desiccated coconut waste meal (DCWM) had the lowest NSC content. Nutrient contents varied among the AIW. Net gas production ranged from $7.7-23.1$ $\mathrm{ml} / 24 \mathrm{~h}$ and significant differences $(P<0.05)$ were observed among the $A I W$ in net gas production. The lowest and highest gas productions were obtained in cocoa dust (CD) and wheat bran (WB), respectively. True dry matter and NDF digestibility were also significantly different $(P<0.05)$ among the AIW. True dry matter and NDF digestibility ranged from $61.1-76.0$ and $52.4-64.1 \%$, respectively. OM digestibility and $M E(M J / \mathrm{kg}$ of DM) values showed significant differences among the AIW. AIW with high OM digestibility also had higher ME values. Statistical significant differences $(P<0.05)$ were obtained among the $A I W$ in the rate $c\left(\mathrm{ml}^{-1} \mathrm{~h}^{-1}\right)$ and potential extent $b(\mathrm{ml})$ of gas production. Chemical analysis data proved that they possess reasonable $C P$, varied NDF, OM and gross energy ( $\mathrm{MJ} / \mathrm{kg} \mathrm{DM}$ ). In vitro digestibility data demonstrated that net gas production $N D F$ and $O M$ digestibility and $M E(M J / k g$ DM) varied based on the type of AIW. The results obtained demonstrated that from chemical composition and net gas production, estimates of nutrients digestibility (OM, NDF and true dry matter) of AlW in the Pacific Island countries could be readily accomplished by the in vitro gas production techniques. The AIW investigated had OM digestibility of between $17.9 \quad 47.6 \%$ and ME values that ranged from $4.2-6.5 \mathrm{MJ} / \mathrm{kg} \mathrm{DM}$. Finally this investigation demonstrated that available AIW in the Pacific Island countries have potential as animal feedstuffs.
\end{abstract}

Keywords: Agro-industrial waste, in vitro, organic matter, neutral detergent fibre, digestibility, metabolizable energy, gas production 


\section{Introduction}

Agro-industrial wastes (AIW) may be defined as those materials that remain after the main product of interest has been removed or extracted in an industry. They result from the processing of crops and in most situations confined to factory sites. Some could be marketed and exported for foreign exchange. These products are now being evaluated to determine their suitability as animal feeds in the small Pacific Island countries in the South Pacific region. Agro-industrial wastes of economic value in the region are brewers' grains, cocoa by-products (cocoa shell and cocoa dust), desiccated coconut waste, wheal bran and rice bran. Most of these by-products are discarded in the small Pacific Island countries.

Brewers' grains, the most important by-product resulting from the manufacture of beer, are the extracted residues of malt (generally barley). They contain the insoluble material remaining after the process of mashing and cooking with water which include the fibre fractions, fats, proteins, together with residues of starch and dextrin. It constitutes an important by-product and the major use of this material has been as a feed for livestock. After drying that is performed to allow storage and improve nutrient concentration, the product becomes known as dried brewers' grains. The concentration of fibre fractions and the low protein degradability means that brewers' grains are preferentially used for feeding ruminants (Bovolenta et al. 1998). In most Pacific Island countries, it is available and wasted. The product can be fed wet or dry to livestock.

Cocoa shell (CS) and cocoa dust (CD) are the waste by-products from the manufacture of chocolate. There is dearth of information on the utilization of cocoa shell (CS) and cocoa dust $(C D)$ in ruminant nutrition in the region, however, their utilization in livestock rations have been reported (Hutagalung, 1978; Greenwood-Barton, 1985). The value of these byproducts as possible livestock feed has received very little attention in the Pacific Island countries because they have not been previously considered important in ruminant nutrition (Aregheore, 2001a).

Desiccated coconut waste meal (DCWM) is one of two important by-products of the coconut industry. DCWM is a by-product from coconut cream production and has tremendous potential as a feed resource in the region. DCWM is often discarded in both urban and rural areas. As a feed it is ideal for ruminants either in the wet or dry form, however, in the wet form it does not keep for a long time before fermentation sets in (Aregheore and Tunabuna, 2001).

Wheat bran or mill mix is a by-product of flourmills and it has a wide acceptance in the diets of livestock. This is commercially available and extensively used in ruminant nutrition where it exists. Wheat bran could be low or high in fibre depending on the processing methods used and it is usually low cost and low energy material. It is used by feed-millers when they want to make cheap or formulate low energy diets (Olomu, 1996).

Rice bran is the ungraded by-product obtained in the processing of rice grains for human consumption. It is a good concentrated ingredient for ruminants. It has a moderate concentration of fibre and it is used as filler in most formulated diets for livestock (Aregheore, 200lb).

These AIW could contribute to dicts of ruminant livestock in the region if properly hamessed and processed. They contain little economical value as edible foods for human consumption therefore they could be used as major sources of dietary 
nutrients and energy in livestock production. They could account for the entire non-forage portion of the diet of ruminant livestock in the Pacific Island countries.

In the Pacific Island countries, little research has been done to characterize them for nutrient contents and evaluate them as potential feed resources. However, it has been observed that some significant variability exist in chemical composition of some available AIW (DePeters, et.al. 1997) At present attempts are therefore been made to include them in rations for ruminants (Aregheore, 2000, 2001b, 2001c, 2002).

Cumulative gas production from the incubation of feedstuffs using rumen liquor or fresh faecal samples suspension as innoculum in vitro together with crude nutrient composition can be used to predict organic matter digestibility and metabolizable energy content of ruminant feeds with high accuracy (Menke et al. 1979; Menke and Steingass, 1988; Akher et al. 1999). There is scant information on the use of gas production techniques to determine OMD and ME of AIW. The objectives of this study were to estimate the organic matter digestibility and metabolizable energy content of some agro-industrial wastes from the Pacific Island countries used as ruminant feeds from in vitro gas production technique.

\section{Materials and Methods}

\section{Feed ingredients preparation.}

Brewers' grains were collected wet from Western Samoa Breweries Ltd, Apia. These were spread in an open but concrete floor, turned regularly until they were dry. Desiccated coconut waste meal was collected wet from Samoa Tropical Products LTD, Apia. This was dried under shade for 4 - 7 days until the product became brown.
During the period the product was continuously turned for even drying and proper aeration. Cocoa shell (CS) and cocoa dust (CD) were obtained from Wilex C \& C Products Ltd., Moatia, Apia. Wheat bran and rice bran were obtained from the Flourmills of Fiji (FMF), Suva and Rewa Rice Mill, Nasourii, Fiji, respectively. Nutritional evaluation using in vitro gas method

Samples were incubated in vitro with rumen fluid in calibrated glass syringes following the procedure of Menke and Steingass (1988). Rumen liquor was obtained from three mature sheep (crossbred Suffolk; mean live-weight of $65 \mathrm{~kg}$ ) fed with $800 \mathrm{~g}$ DM timothy hay (Phleum pratense) and $200 \mathrm{~g}$ DM concentrate, twice daily and had free access to water and mineral mix. About $200 \mathrm{mg}$ of $1 \mathrm{~mm}$ milled samples were weighed into $100 \mathrm{ml}$ calibrated glass syringes in duplicate. Pure oil was applied to the piston to ease movement and to prevent escape of gas.

The syringes were pre-warmed $\left(39^{\circ} \mathrm{C}\right)$ for $1 \mathrm{~h}$, before addition of $30 \pm 1.0 \mathrm{ml}$ of rumen-buffer mixture into each syringe. All the syringes were incubated in a water bath maintained at $39 \pm 0.1^{\circ} \mathrm{C}$. Incubations were stopped after $24 \mathrm{~h}$ incubation and gas volume (Gv) was noted. Organic matter digestibility (OMD, \%) and metabolizable energy ( $\mathrm{ME}, \mathrm{MJ} \mathrm{kg}^{-1} \mathrm{DM}$ ) were calculated using the following equations (Menke and steingass, 1988):

$\mathrm{OMD}=14.88+0.889 * \mathrm{Gv}+0.45^{*} \mathrm{CP}+0.65 \mathrm{CA}$, and $\mathrm{ME}=2.20+0.136^{*} \mathrm{Gv}+0.057^{*} \mathrm{CP}+0.0029 \mathrm{CF}$ Where $\mathrm{Gv}$ is $24 \mathrm{~h}$. net gas production $(\mathrm{ml} / 200$ mg DM), CP, CA, and CF are crude protein, crude ash and crude fibre (\%DM), respectively. These equations have been standardized and validated as method to create the $O M D$ and $M E$ prediction equations using data from 400 digestibility trials (in vivo) and the corresponding in vitro gas production tests (Menke and Steingass, 1988). 


\section{True dry matter digestibility}

$500 \mathrm{mg}$ of samples were incubated in a buffered medium containing rumen liquor $(40 \mathrm{ml})$. True dry matter digestibility was determined after 24 $h$ of incubation treating the syringe content with neutral detergent solution to obtain NDF. The determination of true dry matter (DM) and neutral detergent libre (NDF) digestibility were according to the procedures of Van Soest and Robertson (1985);

$\%$ True dry matter digestibility $=$

(Truly digested substrate (DM)) $\times 100$

(Weight of sample DM taken for incubation)

\section{Rate and potential extent of gas production}

The samples $(200-\mathrm{mg})$ were incubated in triplicate in graduated syringes containing $30 \mathrm{ml}$ of in vitro medium containing rumen liquor (Menke et al. 1979). At 2, 4, 6, 8, 10, 12, 24, 36, $48,54,60,72$ and $96 \mathrm{~h}$, gas values were recorded. The mean gas volume readings were fitted to the exponential equation $\mathrm{p}=\mathrm{a}+\mathrm{b}$ (1-e-ct) (Ørskov and McDonald, 1979). Where $\mathrm{p}=$ gas production at time $\mathrm{t} ; \mathrm{a}+\mathrm{b}=$ the potential gas production, $\mathrm{c}=$ the rate of gas production and $a, b$, and $c$ are constants in the exponential equation using Neway' computer program (X.B.Chen, Rowett Research Institute, Aberdeen, Scotland).

\section{Proximate analysis}

Proximate components were analyzed according to AOAC (1995). Fibre analyses [neutral detergent fibre (NDF) and acid detergent fibre (ADF)] were determined by the procedures of Van Soest et al. (1991).

\section{Statistical analysis}

Data obtained were analyzed by ANOVA and significant differences between means were compared using Duncan's multiple range tests with the aid of SAS/STAT program (Statistical Analysis Systems Institute Inc., 1988).

\section{Results and Diseussion}

Table 1 presents the chemical composition of the agro-industrial wastes (AIW). The chemical composition of the AIW varied. Crude protein (CP) content varied from 13.7 in RB to $25.6 \%$ in DBG, while NDF contents ranged from 21.9 $\%$ in RB to $43.2 \%$ in CS. Organic matter (OM) content was in the range of $88.6-95.4 \%$. There were also marked variations in the ether extract (EE) contents of the AIW $(5.5-27.7 \%)$. DCWM had the highest EE content followed by $C D$. The high EE value for DCWM and CD could pose problems such as rumen acidiosis and/or displaced abomasum if they are often used as source of fat or energy in the nutrition of livestock in the Pacific Island countries. DePeters et al. (1997) reported that the inclusion of by-products high in EE could pose problems if they are often used as sources of fat in ruminant diets.

Proximate chemical composition values reported for these AIW are within the values reported by Devendra and Gohl (1970); Gohl, (1981); Oyenuga, (1968) and Aregheore (1992) for similar by-products. The non-structural carbohydrate (NSC) content of the AIW was calculated using the formula NSC $=[100-(\Lambda$ sh $+\mathrm{CP}+\mathrm{EE}+\mathrm{NDF})]$. The NSC estimates for the AIW increased from 7.2-45.6\%. DCWM had the lowest NSC content. It has been observed that in most situations the NSC estimates of AIW are under estimated and implications of such under estimation with respect to production performance of ruminants are unknown (DePeters et al. 1997).

Net gas production, true dry matter (TDM), neutral detergent fibre (NDF) and organic matter (OM) digestibilities and $\mathrm{ME}(\mathrm{MJ} / \mathrm{kg}$ of $\mathrm{DM})$ are presented in table 2. Net gas production ranged from $7.7-23.1 \mathrm{ml} / 24 \mathrm{~h}$. and significant differences $(P<0.05)$ were observed among the AIW in net gas production. The lowest and highest gas 
Table 1: Chemical composition of the Agro-Industrial wastes

Agro-Industrial wastes

\begin{tabular}{lrlllll}
\hline Nutrients (\%) & DBG & CS & CD & DCWM WB & RB \\
\hline Dry matter & 89.5 & 93.0 & $\mathbf{8 8 . 0}$ & 89.6 & 90.4 & 92.0 \\
Crude protein & 25.6 & 13.8 & 15.9 & 22.2 & 19.6 & 13.7 \\
Ether extract & 5.5 & 11.0 & 22.0 & 27.7 & 6.7 & 15.3 \\
Neutral detergent fibre & 41.4 & 43.2 & 38.3 & 42.1 & 40.8 & 21.9 \\
Acid detergent fibre & 26.6 & 29.4 & 24.0 & 28.6 & 11.4 & 16.1 \\
Organic matter & 95.4 & 91.0 & 94.0 & 95.2 & 88.6 & 93.3 \\
Non-structural carbohydrates & 26.9 & 23.0 & 16.8 & 7.2 & 45.6 & 44.4 \\
Gross energy (MJ/kg DM) & 21.6 & 21.3 & 23.3 & 25.1 & 12.9 & 18.6 \\
\hline
\end{tabular}
DBG - Dried brewers' grains; CS - Cocoa shell; CD - Cocoa dust; DCWM - Desiccated coconut waste meal;
WB - wheat bran; RB - Rice bran.

Table 2: True dry matter, neutral detergent fibre (NDF \%) and organic matter digestibilities and metabolizable energy (ME, MJ/kg of DM) Agro-Industrial wastes*

\begin{tabular}{llllllll}
\hline Parameters & DBG & CS & CD & DCWM & WB & RB & SEM \\
\hline True dry matter digestibility & $74.7 \mathrm{a}$ & $61.1 \mathrm{~b}$ & $60.1 \mathrm{~b}$ & $71.8 \mathrm{a}$ & $76.0 \mathrm{a}$ & $63.1 \mathrm{~b}$ & 6.55 \\
NDF digestibility & $64.1 \mathrm{a}$ & $61.5 \mathrm{a}$ & $60.4 \mathrm{a}$ & $62.8 \mathrm{a}$ & $63.2 \mathrm{a}$ & $52.4 \mathrm{~b}$ & 3.91 \\
OM digestibility & $47.6 \mathrm{a}$ & $36.8 \mathrm{~b}$ & $17.9 \mathrm{c}$ & $42.5 \mathrm{a}$ & $44.1 \mathrm{a}$ & $34.3 \mathrm{~b}$ & 9.94 \\
ME (MJ/kg of DM) & 6.4 & 4.2 & 4.8 & 5.3 & 6.5 & 4.5 & 0.89 \\
\hline
\end{tabular}

*DBG - Dried brewers' grains; CS - Cocoa shell; CD - Cocoa dust; DCWM - Desiccated coconut waste meal; WB - wheat bran; RB - Rice bran.

a.b,c. Mean with different letter within rows are significantly different $(P<0.05)$
SEM - Standard Error of Mean

production was obtained in cocoa dust (CD) and wheat bran (WB), respectively. Gas production generally reflect the contents of fermentable carbohydrate or carbohydrate degradation and also probably the nitrogen and lipids (Menke and Steingass, 1988; Blummel et al. 1997; Steingass et al. 1997).

True dry matter and NDF digestibilities were also significantly different $(\mathrm{P}<0.05)$ among the AIW.
True dry matter and NDF digestibilities ranged from $61.1-76.0$ and $52.4-64.1 \%$, respectively. The values obtained for the AIW in NDF digestibility are close to values reported for some agro-industrial byproducts by DePeters et al. (1997). True dry matter digestibility values obtained seems to portray the probably extent of NDF digestibility of the AIW. However, there were no value differences between true dry matter and NDF digestibilities in CS and CD (Table 2). 
Organic matter (OM) digestibility showed significant differences $(\mathrm{P}<0.05)$ among the AIW. However, among the AIW, cocoa dust was an exception because it had a comparably low OM digestibility. The low OM digestibility obtained for the CD may not be unconnected with the presence of the alkaloid, theobromine it contained (Aregheore, 2001 b). The presence of this anti-nutritive factor could affect the bioavailability of nutrients therefore making it impossible for microbes to utilize CD for the production of useful volatile fatty acids the major sources of energy to the ruminant livestock.

The rale $\mathrm{c}\left(\mathrm{ml} / \mathrm{h}^{-1}\right)$ and potential extent $\mathrm{b}(\mathrm{ml})$ of gas production of the AIW are presented in Table 3 and statistical significant differences $(P<0.05)$ were obtained among the AIW. A comparison ofgas production amongst the AIW and concommitant in vitro $\mathrm{OM}$ and $\mathrm{NDF}$ digestibilities indicated that gas production reflects actually substrate fermentation. The potential extent of gas production followed the trend of OMD (Table 3).
The utilization of roughages is largely dependent on microbial degradation therefore the rate and potential extent of gas production would provide a useful basis for the evaluation of the AIW as potential feed resources. Since gas production is dependent on the relative proportion of soluble, an insoluble but degradable and undegradable particles of feed, mathematical description of gas production profiles allows evaluation of substrate and fermentability of soluble and slowly fermentable components of feeds (Getachew et al. 1998).

Based on the above assumption, therefore, it could be adduced that among the AIW studied, $\mathrm{CS}$ and $\mathrm{CD}$ would provide minimal proportion of residue that would take up space if utilized in in vivo studies and also persists as indigestible residues. Orskov and Ryle (1990) reported that the rate $(c)$ determines digestion time and consequently how long a potentially digestible material would occupy space. Therefore the potential extent of digestion $(b)$ values obtained for DBG, DCWM and WB demonstrated that

Table 3: The rate (c) and the potential extent (b) of gas production of the Agro-Industrial wastes

Gas Production

\begin{tabular}{llll}
\hline Agro-industrial wastes & $\begin{array}{c}\text { Net gas produced } \\
(\mathbf{m l} / \mathbf{2 4} \mathbf{~ h})\end{array}$ & Rate c $\left(\mathbf{m l} / \mathbf{h}^{-1}\right)$ & Potential b (ml) \\
\hline Dried brewers' grains & $20.5 \mathrm{a}$ & $0.0276 \mathrm{~b}$ & $44.696 \mathrm{a}$ \\
Cocoa shell & $7.7 \mathrm{c}$ & $0.1979 \mathrm{a}$ & $8.504 \mathrm{c}$ \\
Cocoa dust & $13.6 \mathrm{~b}$ & $0.2195 \mathrm{a}$ & $10.239 \mathrm{c}$ \\
Desiccated coconut waste meal & $8.9 \mathrm{bc}$ & $0.0761 \mathrm{~b}$ & $17.669 \mathrm{~b}$ \\
Wheat bran & $23.1 \mathrm{a}$ & $0.1046 \mathrm{a}$ & $19.436 \mathrm{~b}$ \\
Rice bran & $11.5 \mathrm{~b}$ & $0.0701 \mathrm{~b}$ & $9.667 \mathrm{c}$ \\
SEM & 5.73 & 0.069 & 12.48 \\
\hline
\end{tabular}

a,b,c, Mean with different letter within a column are significantly different $(\mathrm{P}<0.05)$

SEM - Stardard Error of Mean 
they possess more potentially degradable and fermentable carbohydrates than CS, CD and RB. Also the results presented in Table 3 actually demonstrated that digestion rate $(c)$ and potential extent $(b)$ of gas production provided a more meaningful index of nutritional value than ultimate digestibility comparatively. However, the conversion of true fermented organic matter into gas varied with the type of AIW.

\section{Conclusion}

In conclusion the AIW investigated possessed reasonable $\mathrm{CP}$, varied $\mathrm{NDF}$ and $\mathrm{OM}$ and gross energy (MJ/kg DM). In vitro digestibility data demonstrated that net gas production, NDF and $\mathrm{OM}$ digestibilities and $\mathrm{ME}(\mathrm{MJ} / \mathrm{kg} \mathrm{DM})$ varied based on the type of AIW. The results obtained demonstrated that from the chemical composition and net gas production, estimates of nutrients digestibility (OM, NDF and true dry matter) of AIW in the Pacific Island countries could be readily accomplished by the in vitro gas production techniques. The agro-industrial wastes investigated had OM digestibility of between $17.9-47.6 \%$ and ME values that ranged from $4.2-6.5 \mathrm{MJ} / \mathrm{kg}$ DM. Finally this investigation demonstrated that available AIW in the Pacific Island countries have potential as ruminant livestock feedstuffs if properly harnessed.

\section{References}

Akhter, S., E. Owen, M.K. Theodorou, E.A. Butler and D. J.Minson (1999). Bovine faeces as source of micro-organisms for the in vitro digestibility assay of forages. Grass and Forage Science, 54:219-226.

AOAC (1995) Official Methods of Analysis, $16^{\text {t }}$ edn. (Association of Official Analytical Chemists, Arlington, VA).

Aregheore, E.M. (1992) Chemical composition of some Zambian crop residues for ruminant livestock. Zambia Journal of Agricultural Science, 3:7-10.

Aregheore, E.M. (2000) Crop residues and agro-industrial by products in four Pacific Island countries: Availability, Utilization and Potential value in ruminant nutrition. Asian-Australasian Journal of Animal Sciences, 13 Supplement July 2000 B: 266- 269.

Aregheore, E.M. (2001a). Chemical evaluation and digestibility of cocoa (Theobroma cacao) byproduct diets fed to goats. Tropical Animal Health and Production, Vol. 34 (in press).

Aregheore, E.M. (200 lb) Traditional Staple Foods and Some Feed stuffs of the Pacific Islands: their chemistry, biochemistry and nutrient composition. IRETA Print Media Unit, IRETA, USP, Alafua Campus, Apia, Samoa. 65 pp. (ISBN: 982-175-146-6).

Aregheore, E.M. (2001c). Availability and Utilization of Local Feed Resources in Sustainable Ruminant Livestock Production in the South Pacific Region. In: Aregheore, E.M., Umar, $M$ and Adams, E (eds). Sustainable Ruminant Livestock production in The South Pacific Region. Proceedings of the regional Workshop held on June 25 - July 2, 2001 at Hotel Peninsula, Suva, Fiji Islands. IRETA Print Media Unit, Alafua Campus, Apia, Samoa. Pp. 11-20.

Aregheore, E.M. (2002). Conventional and nonconventional feedstuffs common in the nutrition of ruminant and monogastric livestock in the South Pacific region: Possible levels of inclusion in diets for efficiency. Aregheore, E.M. and Umar, M. (eds). Formulation and utilization of feeds for livestock production using locally available feed resources in the South Pacific region. Proceedings of the regional Workshop held on June 24 - 28, 2002 at Hotel Peninsula, 
Suva, Fiji lslands. IRETA Print Media Unit, USP, SOA, Alafua Campus, Apia, Samoa. Pp. 46-63.

Aregheore, E.M. and T. Tunabuna (2001). Utilization of diets containing increasing levels of dried desiccated coconut waste meal by growing Anglo-Nubian goats in Samoa. AsianAustralasian Journal of Animal Sciences, 14(3):316-320.

Blummel, M., H.P.S. Makkar, G. Chisanga, J. Mtimuni and K. Becker (1997). The prediction of dry matter intake of temperate and tropical forages from in vitro digestibility/gas production data, and the dry matter intake and in vitro digestibility of African roughages in relation to ruminant live-weight gain. Animal Feed Science and Technology, 69:131-141.

Bovolenta, S., E. Piasentier, C. Perseeon and F. Malossini (1998). The utilization of diets containing increasing levels of brewers' grains by growing lambs. Animal Science, 66:689-695.

Depeters, E.J., J.G. Fadel and Arosemena, A. (1997). Digestion kinetics of neutral detergent fibre and chemical composition within some selected by-product feedstuffs. Animal Feed Science and Technology, 67:127-140.

Devendra, C. and B.I. Gohl (1970). The chemical composition of Carribbean Feedingstuffs. Tropical Agriculture, 47(4):335342.

Getachew, G., M. Blummel, H.P.S. Makkar and K. Beckèr (1998). In vitro gas measuring techniques for assessment of nutritional quality of feeds: a review. Animal Feed Science and Technology, 72:261-281.
Greenwood-Barton, L.H. (1985). Utilization of cocoa by-products. Feed Manufacture, 10(5):5256

Gohl, B. (1981). Tropical Feeds: Feed information summaries and nutritive values. FAO Animal Production and Health Series. No. 12. FAO, Rome.

Hutagalung, R.I. (1978). Nontraditional feedstuffs for livestock. In: Devendra, C and Hutagalung, R.I Eds.: Feedingstuffs for livestock in South East Asia. Malaysian Society of Animal Production, Kuala Lumpur, 259-288.

Menke, K.H. and Steingass, H. (1988). Estimation of the energetic feed value from chemical analysis and in vitro gas production using rumen fluid. Animal Research and Development, 28:7-55.

Menke, K.H., L. Raab, A. Slewski, H. Steingass, D. Fritz and Schnieder, W. (1979). The estimation of the digestibility and metabolizable energy content of ruminant feedstuffs from the gas production when they are incubated with rumen liquor. Journal of Agricultural Science (Cambridge), 93:217-222.

$\varnothing$ RSKOV, E.R and Medonald, I. (1979). The estimation of protein degradability in the rumen from incubation measurement weighted according to rate of passage. Journal of Agricultural Science, Cambridg, 92:499-503

$\varnothing$ Rskov, E.R. and M. Ryle (1990). Feed quality and feed intake. In: Energy Nutrition in Ruminants. Elsevier Applied Science, London and New York, Chapter 8. Pp. 102-121. 
Olomu, J.M. (1996). Nature's most nearly perfect food. Inaugural Lecture Series 45, University of Benin, Benin City, Nigeria. 64 pp.

Oyenuga Va (1968) Nigeria's Foods and Feeding-stuffs. Their chemistry and nutritive value 3rd ed. Ibadan Univ. Press. Ibadan, Nigeria. $99 \mathrm{pp}$.

Statistical Analysis Systems Institute Inc. (1988). SAS/STAT Program, Cary, NC: SAS Institute Inc.

Steingass, H., P. Aiple and Drochner, W. (1997) Estimation of organic matter digestibility and $\mathrm{ME}$ content in ruminant feeds from in vitro gas production. Session 17 - Forage Quality,
Proceedings of International Grassland Congress, Canada, 17-79-17-80.

Van Soest P.J. and J.B. Robertson (1985). A laboratory Manual for Animal Science 615. Cornell University. $252 \mathrm{pp}$.

Van Soest, P.J., J.B. Robertson and B.A. Lewis, (1991). Methods for dietary fibre, neutral detergent fibre and non-starch polysaccharides in relation to animal nutrition. Journal of Dairy Science, 74:3583-3597.

(Received 31 July 2003; Accepted 19 November 2003). 